BABELAO 5 (2016), p. 301-329

(C) ABELAO (Belgium)

\title{
Collective Nouns in Journalistic Modern Standard Arabic
}

Par

\section{Yehudit Dror}

University of Haifa

\section{Definition of the Term, Collective Noun}

\subsection{Collective nouns in Western descriptions}

$\Lambda$ ccording to Lyons, «Collective nouns may be defined semantically as lexemes which denote collections or groups of persons and objects.» ${ }^{1}$ The following examples are considered to be collective nouns in English: army, audience, committee, family, staff, team, flock and bunch. In the category of collective nouns there are also proper nouns naming official bodies or organizations, e.g., the UN, Congress, Parliament and the $\mathrm{BBC} .^{2}$ Collective nouns can cover a range of meanings and can thus be divided into three classes:

a. Groups, e.g., team, family, staff. These nouns are the most general words, allowing for the widest range of associations.

1 J. LyOnS, Semantics, Cambridge, 1987, p. 315.

2 D. BIBER AND C. LEECH, Longman Student Grammar of Spoken and Written English, Harlow, Essex, 2002, p. 61. 
Moreover, they can accept the plural marker $-s$, and can therefore be called collective count nouns. ${ }^{3}$ Biber and Leech suggest calling this group of-collectives because they are generally followed by an of + plural noun, where the plural indicates the individuals. ${ }^{4}$ Thus, for example, the collective noun, group, has a general meaning, while an utterance such as a group of adults, girls, animals, buildings, things has a more specific application.

b. Classes, e.g., aristocracy, clergy, proletariat. As opposed to the first group, the collective nouns belonging to this category are rarely pluralized or followed by the of + plural noun structure. This group consists of generic collectives because they always refer to all the members of a class and never to the individuals comprising this group.

c. Collections, e.g., forest, herd, library. The collective nouns classified in this group designate the non-human. ${ }^{5}$

Some additional differences between the collective nouns presented above should be mentioned. Some of the collective nouns can accept the plural marker $-S$ and therefore can be labeled as individual collective nouns or collective count nouns, as in family and families, buffalo and buffaloes. On the other hand, collective nouns such as deer, cattle, clergy and police cannot be used in English as count nouns, i.e. the plural $-s$ marker cannot be a suffix to these nouns. Furthermore, it is not always possible to add a quantifier before the collective noun, as, for example, one might say four buffalo and some buffalo while some government and some aristocracy are grammatically incorrect. Collective nouns are also differentiated by their singular form. Some of them have a form-match individual noun, e.g. buffalo is also the singular form of the collective noun buffalo. In contrast, the collective noun army has a semantically-related individual noun, which would be soldier. ${ }^{6}$

Scholars usually distinguish between collective nouns indicating human and collective nouns indicating non-human. One reason for this distinction arises from the fact that inanimate nouns can be also characterized by the lack of volition, i.e., they cannot express any wish, desire or will and sometimes they lack mobility, i.e., the possibility of moving. ${ }^{7}$

\footnotetext{
${ }^{3}$ I. DEPRAETERE, «On Verbal Concord with Collective Nouns in British English», English Language and Linguistics 7.1(2003), p. 88-89.

4 BIBER AND LEECH, p. 61.

5 DEPRAETERE, p. 182.

${ }^{6}$ K. Bock AND K.M. EBERHARD, «Meaning, Sound and Syntax in English Number Agreement», Language and Cognitive Processes 8.1 (1993), p. 81 .

${ }^{7}$ DePRAETERE, p. 182.
} 
The following exemplifies the difference between human and non-human collective nouns:

\begin{tabular}{|l|l|}
\hline Example & + - volition or mobility \\
\hline $\begin{array}{l}\text { The family has decided to go } \\
\text { on vacation to London. }\end{array}$ & $\begin{array}{l}\text { +volition. } \\
\text { The family has the will and } \\
\text { the ability to go on vacation. }\end{array}$ \\
\hline $\begin{array}{l}\text { The army withdrew from this } \\
\text { area. }\end{array}$ & $\begin{array}{l}\text { +mobility } \\
\text { The army has the ability to } \\
\text { move. }\end{array}$ \\
\hline The forest was burned. & $\begin{array}{l}\text {-mobility } \\
\text { The forest cannot escape, i.e., } \\
\text { the ability to move. }\end{array}$ \\
\hline The library was painted. & $\begin{array}{l}\text {-volition } \\
\text { The library cannot express the } \\
\text { will to be painted. }\end{array}$ \\
\hline
\end{tabular}

The collective noun is usually classified as or considered to be a plural form. ${ }^{8}$ However, plurality is a complex phenomenon due to the morphological variations of this form. Thus, we may distinguish between two primary types: the first is a marked plural, i.e. the plurals are formed by adding a certain suffix or prefix, and the second is regarded as an unmarked plural. In this case, there are no morphological signs indicating that the noun is singular or plural, and therefore at the referent level one might accept or reject the notion of plurality and thus the unmarked form can be ambiguous. ${ }^{9}$

In English, for example, the collective nouns fall into several different grammatical classes. Thus, the collective noun cattle can be treated as plural, while furniture is treated as a singular noun. Some ambiguity might be found, however, regarding the number of the collective noun. The collective noun family, for example, can be considered as a singular noun, as in the family has decided. A sentence in which family is considered as a plural noun is also acceptable, e.g., the family have decided. The grammatical ambivalence of many collectives with respect to the distinction of singular or plural can be explained by the fact that a collective can be regarded as a single entity on one hand and, on the other, can be regarded as plural, or, more accurately, the individuals are being considered. ${ }^{10}$ The reference to

\footnotetext{
${ }^{8}$ D.A. CRUSE, «Number and Number System», in The Encyclopedia of Language and Linguistics, vol. 5, Oxford and New York, 1994, p. 28572861.

9 A. RozUmKO, «Countable, Uncountable and Collective Nouns in the Early Eighteenth Century English», Studia Anglica Posnaniensia 32 (2002), 132. Cf. BOCK AND EBERHARD, p. 61.

${ }^{10}$ LYONS, p. 315.
} 
the collective noun as singular or plural can be discovered only when different syntactic elements agree with it.

In the following examples, there are different agreement types with the same noun:

The Government have decreed that we will have to rebid for our betting license.

The Government has decreed that we will have to rebid for our betting license.

In the first example, the collective noun Government is treated as plural. Nearly all human collective nouns occasionally occur with plural agreement in British English. In the second example, the agreement is in the singular, which is the norm in American English. ${ }^{11}$ These two examples indicate two types of agreement with collective nouns. When the syntactic element matches the noun in number, it may be called grammatical agreement. In the sentence The Government has decreed, the verb in the singular agrees with a noun that is grammatically singular.

The second type, the notional agreement, exists when the elements agree with the subject according to the notion of number rather than with the nouns' grammatical marker. Thus, in the sentence The Government have decreed, the noun is considered as collection of individuals and not as a single undivided body. ${ }^{12}$

Distinction between grammatical agreement and notional agreement is not always the acceptable or the rational explanation for agreement types especially when a sentence such as The family has decided to travel to New York so they looked in the Internet for cheap tickets. The family is first referred to as singular and then as plural. The shift from the singular to the plural agreement is not random. Singular forms are far more likely to be followed by the plural than vice versa. Moreover, the distance between a node word and concord mark may affect the agreement by increasing the likelihood of an agreement in the plural. Another factor that causes the mixed agreement is semantic memory rather than syntactic-lexical memory. It has been shown that the meaning of a sentence is more easily re-

\footnotetext{
11 BIBER AND LEECH, p. 235

${ }^{12}$ R. Quirk, S. GReEnBAuM, G. LeEch And J. Svartvik, A Comprehensive Grammar of the English Language, London and New York, 1986, p. 757-758. Cf. M. LEVIN, «Concord With Collective Nouns Revisited», ICAME Journal, 23(1999), p. 21. K.R. HUMPHREYS AND K. BOCK, «Notional Number Agreement in English», Psychonomic Bulletin \& Review 12.4(2004), p. 689, explain the difference between notional number and grammatical number as follows: «Notional number is the numerosity of the subject's referent in the speaker's mental model, and grammatical number is the conventional linguistic number of the subject (head) noun.»
} 
membered than the form, both in long-term memory and in short-term memory. ${ }^{13}$

Referring back to the examples, the family has decided vs. the family have decided, the usage of the verb in the singular or in the plural is possible because the verb might refer to the family as a group or to the various members of the family. However, when an adjective is involved, it cannot always refer to the members. A collective noun is highly variable if the adjective that modifies it cannot refer to the characteristics of the individuals in the group, as, for example, in the utterance $a$ big family does not mean that each member in the family is big (if, for example, there are babies) whereas in the example a beautiful family the adjective refers to all the members making a beautiful unit. ${ }^{14}$

\subsection{Collective Nouns in Arabic}

\subsubsection{Collective nouns in the traditional Arabic thought}

We commence our review of this linguistic phenomenon in Arabic by referring to Sỉbawayhi's definition of the term, collective noun:

mā kāna wāhhidan yaqa'u li-l-ğamì'i wa-yakūnu wāhiduhu 'alā binā'ihi min lafẓihi, 'illā 'annahu mu'annatun talhaquhu hā'u t-ta'nīti li-yatabayyana l-wāḥidu mina lgamī' $i$

«The collective noun is morphologically singular but indicates plural (or a group). Its singular has the same morphological form of the collective noun, except for the fact that the singular form is feminine, due to the addition of a feminine singular suffix, and thus the singular is distinguished from the group.»

Sībawayhi presents numerous examples of these types of collective nouns which are called 'asmā' al-ğins, dividing them according to their morphological pattern, e.g., the pattern $f a l$ as in tamr «dates», tamra «one date», whereas tamarāt indicates the plural of paucity, nouns of the pattern fa'ul, e.g. samur «acacia» (also known as thorntree) and samura «one acacia» and nouns of the pattern $f u$ ' $l$, e.g. burr «wheat», burra «one straw», «one stalk of wheat» and burrät «a small number of straws». ${ }^{15}$

The collective nouns of this group have the so-called formmatch individual noun, i.e., nomen unitatis. There is an additio-

13 LEVIN, «Concord with Collective Nouns», p. 29.

${ }^{14}$ Depraetere, p. 88. Cf. F. JoOsten, «De Boorbaarheid van Nederlandse Collectiva», Over Taal 40 (2001), p. 77-79.

${ }^{15}$ SīBAWAYHI, al-Kitāb, Beirut, 1999, vol. 3, p. 583-585. 
nal group of nouns called 'asmā' al-ğam 'or 'ašbāh al-ğam ', 16 which, like the former, indicates the group or the members of the group, but possesses no nomen unitatis, and thus these words are described by traditional Arab grammarians as al-ism llad̄i yaqa'u 'alā l-ğamī'i lam yukassar 'alayhi wāhiduhu «nouns which indicate plural, and a singular form cannot be derived from this noun [by adding a feminine suffix to the noun].» Examples of such nouns are qawm «tribe» or rakb «traveling party», which indicates the group, but cannot be considered to be broken plurals, i.e., rakb is not the plural of rākib «rider» ${ }^{17}$. This type of collective noun has a semanticallyrelated individual ${ }^{18}$, i.e., the singular of qawm would be rağul «a man».

According to Mubarrd, nouns of this group can be counted when a qualifier precedes them, as for example talâtun mina $l$ 'ibili «three camels». ${ }^{19}$

Ibn Ya'ǐš mentions also nouns with feminine marks indicating both plural and singular. This group includes different kinds of plants, as in tarfä' "tamarisk» (many trees of this kind or one tree) and half $\bar{a}$ ' "esparto» (many sorts of grass or one sort) ${ }^{20} \mathrm{Ibn} \mathrm{Ya} \mathrm{Y}^{\leftarrow} \overline{1} \mathrm{~s}$ is one of a few grammarians who discusses albeit briefly the issue of agreement. He mentions examples in which the noun can be followed by an adjective in the singular, as, for example, 'a ' $\breve{g} \bar{a} z$ nahl mun 'aqir «uprooted stems of datepalms» or a nominal predicate in the plural, as in al-nahl bāsiqāt «the date-palms are tall». ${ }^{21}$

1.2.2 The term, collective nouns, in Western descriptions of modern standard Arabic

Since this paper concerns modern standard Arabic it is worth mentioning that the development of the language may be roughly divided into four varieties. Old Arabic or classical Arabic: this blanket term refers to the Arabic from the period of pre-Islamic Arabia. Both the pre-Islamic poetry and the Qur'ān have a primary role in the standardization process of Arabic

16 These terms are mentioned by Fischer (1940, p. 12-13) based on Wright (1971, part II p. 180-181, 234). The same classification is presented by Blachère (1958, p. 31-32), Fleisch (1961, p. 310), Brockelmann (1965, p. 93-94), Fleischer (1968, vol. 1, p. 256-257) and Fischer (2002, p. 49-50).

${ }^{17}$ IBN YA'Ī̌̌, Šarḥ al-mufașșal, Beirut 1994, vol. 1, p. 29

18 BOCK AND EBERHARD, p. 81.

${ }^{19}$ AL-MuBARRAD, al-Muqtadab, Beirut, 1994, Vol. 2, p. 186.

${ }^{20}$ IBN YA'ĪǏs, vol. 1, p. 29.

${ }^{21}$ IBID., vol. 1, p. 71.

These two examples are mentioned by Fleischer (1968, vol. 1, p. 257); however, he provides no explanation for the agreement types. 
language, and making it the accepted language in various fields such as trade, education, media and governance.

The term Neo-Arabic signifies a variety of the spoken Arabic which was already in existence in the initial stages of the Islamic conquest and developed into the modern dialects. There are various theories explaining the emergence of New Arabic. According to one opinion the shift from Classical Arabic to New Arabic took place as early as the pre-Islamic period in the colloquial language of the Arab tribes. ${ }^{22}$ Middle Arabic refers to the language written mostly by non-Muslims and characterized by deviations from the classical rules of Arabic. ${ }^{23}$ Modern Standard Arabic has emerged due to the influence of new Western knowledge in various fields such as science and philosophy, the invention of the printing press and the rise of the media, which led to the introduction of lexical and grammatical changes in Arabic language. ${ }^{24}$

As for the term, collective nouns, in the research literature of modern Arabic, it is usually discussed indirectly as an item of the grammatical categories, number and gender. Holes, for example, explains the collective nouns as follows when discussing number in modern written Arabic:

«There exists a separate category of collective nouns which is used, in roots where it exists, to refer to uncountable nouns or to plural entities (usually humans, animals and other classes of living things such as fruit, vegetables, trees, etc.) as an undifferentiated group. For example naxl is a collective used when reference is made to palm trees in general, whereas naxi:l means, '(particular) palm-trees'. From the collective is derived the instance noun by the suffixation of the feminine endings $-a$, e.g. naxla 'a (single) palm-tree'.» ${ }^{25}$

Only a few Western grammarians refer exhaustively to the category of collective nouns in modern written Arabic. One source worth mentioning is Fischer et al. (2001). Their contribution to the issue of collective nouns lies in the fact that they tries to present some new collective nouns illustrated by examples from modern literature, and not only the classical examples. After a short definition of the term, collective noun, which is not much different from that presented by Holes, Fischer et al. continue by presenting the different groups of the collective nouns. Their division is based on that of the traditio-

22 IBID., p. 102.

23 IBID., p. 115.

${ }^{24}$ IBID., p. 183.

${ }^{25}$ C. Holes, Modern Arabic: Structures, Functions, and Varieties, London, 1995, p. 133. 
nal grammarians, i.e., human vs. non-human, with or without nomen unitatis.

Fischer et al. begin with collective nouns that have a singular form. In the first group they mention collective nouns denoting animals, plants and material. Then after speaking about the familiar collective nouns such as šăgar «trees» and šăgara «a (single) tree», they mention a new noun - sandwiš «sandwich» and sandwiša «one sandwich». The agreement with these nouns is in the singular, i.e., in accordance with the morphological form of the collective noun, as, for example, in: $l$ lu'lu'u ș-șinā 'iyyu l-yābāniyyu «the industrial Japanese pearls». In the second group he classifies collective nouns - human and non-human; their singular is an active participle, e.g., țayr «bird» (generic noun) and țâ'ir «one bird», haras «guard» and hāris «watchman», talaba «students» (as a group) and țālib «one student».

The agreement with the collective nouns designating the non-human is usually in the singular, while the agreement in the plural is seen with collective nouns designating the human, as in: man lä ya 'rifu t-țayra yašwīhi «(he) who does not know the bird, roasts it» or yulāhizu l-maliku 'anna hadama l-qașri qad tarakū 'a 'mālahum «the king noticed that the servants had abandoned their duties». ${ }^{26}$ Fischer et al. continue to discuss collective nouns that designate a collection of people, animals or things, as, for example, $\breve{g} \bar{l} l$ «generation», šurța «police» and ğama' 'a «group», «band», «troop», «gang». Most of these nouns do not have a singular form. In the case of nouns designating the human, the singular form is achieved by suffixing $y \bar{a}$ ' $n$-nisba «the termination ي" It is added to the word to denote that a person or a thing belongs to or is connected to a specific origin, family, sect etc., e.g., šurtiyy «policeman«. Some additional examples of this type of collective noun are: ğumhür «public», ša $b$ «folk», «people» and farīq «team», «band», «troop». The agreement with such nouns, according to Fischer et al., is in the singular feminine in accordance with their morphological marks, as in: (...) fa-'id̄a ğamā 'atun mina n-nāsi waqafat 'amāma bābin muǵlaqin «and there (suddenly) a group of people stand in front of a closed door.» Agreement in the plural can also be found in the example wa-la șahhata li-

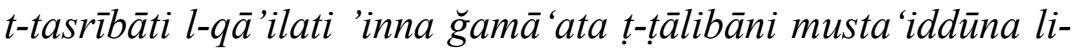
taslimihi 'ilä l-'amìrikiyyina «there is no truth in the reports saying that the organization of the Taliban is willing to hand it over to the Americans». ${ }^{27}$

\footnotetext{
${ }^{26}$ W. FisCher, H. El-AYOUBI AND M. LANGER, Syntax der arabischen Schriftsprache der Gegenwart, Wiesbaden, 2001, p. 90-97.

${ }^{27}$ FISCHER ET AL., p. 91-93.
} 
To the collective nouns also belong names of geographical areas, as for example, fa-'inna min 'abrazi timāri ziyāratihi li'ūrūbbā 'iqrāruhum mu'aḩharan bi-ḥuqūqi l-'insāni fì $l$ yamani «and from the outstanding results of his visit to Europe came their last decision on human rights in Yemen.» In this example, Europe is considered as plural. Names of peoples, countries and ethnic groups also belong to the collective nouns, as, for example: $s^{\prime}{ }^{\prime} a$ «the Shiah», sunna «the Sunna», qibt «Copts» and 'almān «Germans». The agreement with these nouns might be in the singular or in the plural, as in fa-'inna šl' 'ata l- 'irāqi yarawna 'annahum l-mutadarraru l-'akbaru «the shi'a of Iraq see (understand) that they are the most damaged». ${ }^{28}$

To conclude this part, it might be argued that the issue of collective nouns in classical Arabic receives attention in grammar books although it is rarely discussed in modern Arabic research literature. The category of collective nouns is usually mentioned when discussing the question of number in Arabic, presenting several examples, most of which are familiar from classical Arabic. An exception to most scholars are Fischer et al. (2001), who present a list of the collective nouns used in modern written Arabic and provide some observations about the type of agreement. However, their list includes only six nouns used in Arabic language newspapers and those are: $\breve{g} \bar{l} l$,

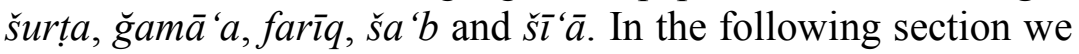
would like to present a more detailed list containing fifty-eight collective nouns used in Arabic newspapers. Although it is an incomplete list, it presents the lexical and syntactic features of this category.

The material for this study comes from five journals in their electronic versions:

1. al-haya (al-Hayat) from 2013

2. aš-šarq al-'awsat from 2001-2015

3. al-'ahrām from1999-2015

4. an-nahār from 2013

5. al-'ayyām from 2013

6. bānūrāmā (see Panet) from 2007-2015

In total, 3,324 items i.e., newspaper articles containing collective nouns, were collected and examined. It should, however, be mentioned in this context that not every collective noun has syntactic elements agreeing with the collective noun. Thus, for example, of the 163 items, including the collective noun baqar, no agreement patterns with this noun were found. Furthermore, it was decided to limit the number of the examined nouns to one hundred; however, in some cases fewer than one hundred items were found.

\footnotetext{
${ }^{28}$ IBID., p. 94-95.
} 


\section{The Data}

Collecting the collective nouns in Arabic involved two obstacles: first, they are morphologically unmarked; and second, there is no dictionary or any other work devoted to collective nouns. As has already been mentioned, the researchers typically used examples from classical Arabic. The researchers of course, are not wrong, because even the following list includes nouns that are found in the Qur'ān, such as: qawm, fi'a, nafar, 'ahl, 'ibl/ 'ibil, nahl and lu'lu'.

Expanding this list is possible due to several works on collective nouns in English, such as those by Sparkes (1975), Levin (2006) and Depraetere (2003). Most of the nouns presented in these works have parallels in Arabic newspapers. But before presenting the examined list, it should be explained why collective nouns are often used in journalistic language. Charles and Many explain the role of collectives in journals as follows:

«This bias of language becomes most apparent when journalists use such collective formations as «the Supreme Court said today,» or «the state legislature has decided to...» we refer to such formations in this article as language collectives. We view language collectives as concepts which exist mainly in their encryption as language terms and not as symbols of truly tangible entities (...) when journalists attribute to language collectives they attempt to walk on semantic water. Terms such as «The Supreme Court» and «The International Society for General Semantics» refer to entities that do not exist in the same way as a pumpkin or you. Language enters here to work its magic. As such terms enter the language, they begin to gain the same status as other terms similarly used that refer to more tangible, unitary entities. Along the way they also pick up other qualities and attributes that generalize from the contexts in which they usually appear. Language collectives result when such rolling snowball terms reach the bottom of the cultural hill and find their way into print.» 29

Using collective nouns in journalistic language may cause two problems. First, when a journalist reports, for example, on a decision of the Supreme Court or of the Congress, s/he might present these bodies as omnipotent, immutable, immortal or monolithic. In other words, they are presented as powerful and undefeated bodies. Secondly, there is a logical mismatch between the lexeme and its meaning. Thus, by saying that the university plans to, for example, or the school intends to, one might wonder how inanimate buildings can take any action. In

29 R. CHARLES AND P. MANY, «How Language Collectives Comprise Journalistic Accuracy», ETC: A Review of General Semantics 51.1(1994), p. 88 . 
these cases, it is clear that the reference is to the people who work in these buildings. Collective nouns such as Congress, the Supreme Court, the CIA, and the White House are considered as a type of metaphorical shorthand. They are used for quickly conveying complex information, or when the source should be kept anonymous. ${ }^{30}$ Secondly, collective nouns such as the city council are presented as powerful bodies, entities that might create a reaction in which the simple man believes he cannot oppose; the same reaction goes for the individual members of the council, and the decisions of the body. Furthermore, such nouns can be vague and inaccurate. Thus, for example, when a journalist refers to a specific minority as a group, it might happen that not all members of this minority act, think and view things alike. ${ }^{31}$

The journalistic use of collective nouns in the USA does not differ from its use in the Arabic journals. Thus the following list includes inter alia metaphorical shorthand, i.e., instead of referring to the people who compose the institutions or other bodies, they are replaced by an inanimate noun such as madra$s a$ «school».

Table A: Collective Nouns Designating the Human

\begin{tabular}{|c|c|c|c|}
\hline Noun & Translation & $\begin{array}{l}\text { Agreement } \\
\text { in singular }\end{array}$ & $\begin{array}{l}\text { Agreement } \\
\text { in plural }\end{array}$ \\
\hline 1. ğay̌̌ & army & + & - \\
\hline 2. 'i'tilāf & coalition & + & - \\
\hline 3. $\breve{g} a b h a$ & $\begin{array}{l}\text { political } \\
\text { frontline }\end{array}$ & + & - \\
\hline 4. hukūma & government & + & - \\
\hline 5. šurța & police & + & - \\
\hline 6. munazzama & organization & + & - \\
\hline 7. mu 'āraḍa & opposition & + & - \\
\hline 8. muqāwama & $\begin{array}{l}\text { opposition, } \\
\text { resistance }\end{array}$ & + & - \\
\hline 9. qiyāda & leadership & + & - \\
\hline 10. $\check{s} a b$ & folk, people & + & - \\
\hline 11. ğamā'a & group, gang & + & - \\
\hline 12. $m a \breve{g} m \bar{u}{ }^{\prime} a$ & group & + & + \\
\hline 13. tā'ifa & sect, class, reli- & + & - \\
\hline
\end{tabular}

$\begin{array}{ll}30 & \text { IBID., p. } 88 . \\ 31 & \text { IBID., p. } 90 .\end{array}$ 


\begin{tabular}{|c|c|c|c|}
\hline & gious minority & & \\
\hline 14. farīq & gang, group & + & + \\
\hline 15. 'ittihāa & union & + & - \\
\hline 16. $\check{s}^{\prime}{ }^{\prime} a$ & the Shiah & + & - \\
\hline 17. qawm & people & - & + \\
\hline 18. mă̆lis & board, council & + & - \\
\hline 19. qabīla & tribe & + & - \\
\hline 20. haraka & $\begin{array}{l}\text { political } \\
\text { movement }\end{array}$ & + & - \\
\hline 21. qāfila & convoy & + & - \\
\hline 22. țāqim & team, crew & + & + \\
\hline 23. firqa & $\begin{array}{l}\text { band, group } \\
\text { company, party }\end{array}$ & + & - \\
\hline 24. 'idāra & management & + & - \\
\hline 25. kūng̀ris & congress & + & - \\
\hline 26. al-yūniskū & UNESCO & + & - \\
\hline 27. hay'a & institution & + & - \\
\hline 28. $b a \underline{t} a$ & delegation & + & - \\
\hline 29. mahkama & court & + & - \\
\hline 30. madrasa & school & + & - \\
\hline 31. ğam iyya & association, club & + & - \\
\hline $\begin{array}{l}\text { 32. nādin, } \\
\text { muntadā }\end{array}$ & club & + & - \\
\hline 33. barlamān & Parliament & + & - \\
\hline 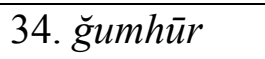 & public & + & + \\
\hline 35. kutla & faction, bloc & + & - \\
\hline 36. hizb & political party & + & - \\
\hline 37. sulta & $\begin{array}{l}\text { government, } \\
\text { authority }\end{array}$ & + & - \\
\hline 38. fi'a & group, class & + & + \\
\hline $\begin{array}{l}\text { 39. aṣ-ṣalīb } \\
\text { l-'aḥmar }\end{array}$ & The Red Cross & + & - \\
\hline 40. $\breve{g} \bar{l} l$ & generation & + & - \\
\hline
\end{tabular}




\begin{tabular}{|c|c|c|c|}
\hline 41. baladiyya & City Hall & + & - \\
\hline 42. nafar & group of people & + & - \\
\hline 43. 'aš̄̄ra & tribe & + & - \\
\hline 44. $m a \check{s} a r$ & $\begin{array}{l}\text { assemblage, } \\
\text { group }\end{array}$ & - & + \\
\hline 45. wizāra & ministry & + & - \\
\hline 46. faw $\breve{g}$ & graduates & + & - \\
\hline 47. liwa & district & + & - \\
\hline 48. 'ahl & family & - & + \\
\hline 49. haliyya & cell & + & - \\
\hline $\begin{array}{l}\text { 50. lubnān } \\
\text { (and other coun- } \\
\text { tries) }\end{array}$ & Lebanon & + & - \\
\hline Total 3272 & & 2802 (sg.) & 470 (pl.) \\
\hline
\end{tabular}

Table B: Collective Nouns Designating Non-human

\begin{tabular}{|c|c|c|c|}
\hline Noun & Translation & $\begin{array}{l}\text { Agreement in } \\
\text { the singular }\end{array}$ & $\begin{array}{l}\text { Agreement in } \\
\text { the plural }\end{array}$ \\
\hline 1.lu'lu' & pearls & + & - \\
\hline 2. samak & fishes & + & - \\
\hline 3. šă̆ar & trees & + & - \\
\hline 4. tuffāh & apples & + & - \\
\hline 5. nahl & bees & + & - \\
\hline 6. 'ibl & camels & + & - \\
\hline 7. da $\breve{g} \bar{a} \breve{g}$ & chickens & + & - \\
\hline 8. bị d & eggs & + & - \\
\hline Total & & 52 & 0 \\
\hline
\end{tabular}

\section{Classification of the Collective Noun}

Since 48 collective nouns out of $50^{32}$ designating humans do not have a singular form achieved by adding the feminine suffix, or as Bock and Eberhard ${ }^{33}$ define them as collective

32 Both nouns lubnān «Lebanon» and šurța «police» can be individualized by adding the termination $y \bar{a}$ ' n-nisba to the noun, e.g., lubnāniyy «Lebanese» and šurțiyy «policeman».

33 BOCK AND EBERHARD, p. 81. 
nouns which have semantic-related individual nouns (as opposed to collective nouns which have a form-match individual noun) and, in addition, they all are collective count nouns, the classical division of the collective nouns based upon whether or not the nouns have a nomen unitatis is no longer valid in journalistic Arabic. The research literature offers different methods of classification and, based on these methods, a different classification of collective nouns in modern written Arabic is proposed.

Aremo distinguishes between two groups of collectives: in the first group belong the singular collective nouns such as Congress, council, government, parliament, and senate; the second group includes collective nouns such as club and public, which in the singular denotes a group of entities and in the plural more than one group of such entities. These nouns are singular in form but plural in meaning — a fact that can explain the agreement with these nouns both in the singular or the plural. $^{34}$

The singular collective nouns can be used as a subject or object but when they are used as a subject they usually have agreement in the plural, as in, for example: Congress think that the case should be re-examined. ${ }^{35}$ The singular collective nouns may be determined or undetermined, and this is also what differentiates such nouns from other collective nouns, such as audience, class, club, crowd, family, party, public and team. Singular collective nouns such as Parliament no longer have any need for the identity-specifying determiner (the), because there is only one parliament in the context in which it is being used. In other words, these nouns have the same value as a proper name, i.e., they have a specific and unambiguous reference.

Thus, one could say Parliament decided but not club decided, only the club decided. Furthermore, all singular collective nouns, unlike other collective nouns, have something to do with a body of persons elected or selected whose task is to direct a larger body, for example city - the city council. ${ }^{36}$

Joosten et al. distinguish between the types of collective nouns according to the two conceptual individuation levels of the collective nouns: The collection level i.e., the collective noun is conceptualized as one (group), and the member level i.e., the collective noun is conceptualized as more than one member or it is viewed in terms of the individual members ma-

\footnotetext{
${ }^{34}$ B. AREMO, «On Some Uses of Singular Collective Nouns», English Today 1 (2005), p. 61.

35 IBID., p. 69.

${ }^{36}$ IBID., p. 72.
} 
king up the collection. Not all collective nouns profile the members of the collection to the same extent; thus in the example an old club, the adjective applies to the collective aspect, while in an old audience, it indicates a characteristic of the members. ${ }^{37}$ After considering this idea, Joosten et al. divide the Dutch collective nouns into three groups:

1. The first group includes collective nouns such as vereniging «association», maatschappij «company», firma «firm», bond «union», club «club», partij «party», organisatie «organization», koor «choir», leger «army», regering «government», orkest «orchestra» and orde «order». The first type of collective noun consists of those nouns that generally trigger collectionlevel interpretations.

2. The second group includes collective nouns such as team «team», bende «gang», familie «family», ploeg «team», staf «staff», redactie «editorial staff», klas «class», jury «jury», panel «panel» and delegatie «delegation». The second type of collective noun seems to occupy a middle position, in the sense that both collection and member-level interpretations are very common.

3. The third group includes collective nouns such as $d u o$ «duo», «pair», echtpaar «married couple», kliek «clique», gezin «family», «household», publiek «public», bemanning «crew», tweeling «twins» and trio «trio, threesome». These nouns generally trigger member-level interpretations. ${ }^{38}$

Based on the data presented in the chart, a classification of the Arabic collective nouns based on the agreement patterns might be considered.

A. There are collective nouns with agreement only in the singular as, for example, hukūma, munazzama, qiyāda, mă̆lis, kūngris, al-yūniskū, barlamān, aș-ṣalīb l-'ahmmar and wizāra. Such nouns are conceptualized as one group and called metaphorical shorthand by Charles and Many (1994). It is possible to classify here also all the nouns that have agreement only in the singular, such as: mu 'ārada, muqāwama, ša $b$ and ța'ifa. The syntactic elements connected to these nouns can refer only to the collective, thus an adjective such as blond, thin, high, wise that characterizes only individuals cannot be attached to these nouns. In the research literature these collective nouns are called wholistic collectives, i.e., nouns with a single group sense or nouns with collection interpretation.

${ }^{37}$ F. Joosten, G. De Sutter G., D. Drieghe, S. Grondelaers, R.J. Hartsuiker AND D. SPEElman, «Dutch Collective Nouns and Conceptual Profiling», Linguistics 45.1(2007), p. 86.

${ }^{38}$ IBID., p. 92-93. 
B. There are collective nouns such as: farīq and tāqim which, according to Joosten et al. (2007), take the middle position. This means that these nouns can have an agreement in the singular or in the plural, i.e., the syntactic elements that agree with the noun might refer to the collection or to the individuals of the group. However, as will be explained in Section 4, agreement in the plural with these nouns can be considered only when they are complex noun phrases, i.e., collective head nouns are embedded by a local noun in the plural. Biber and Leech (2002) therefore call this type of collectives as ofcollectives, namely an utterance structured by of + noun in the plural is introduced after the collective noun. ${ }^{39}$

C. We found only four collective nouns which have an agreement only in the plural and these are: $\breve{s}^{\prime}$ ' $a$, qawm, ma '̌sar (followed by a local noun in the plural) and 'ahl (followed by the name of a city as for example 'ahl n-nāsira «the people/citizens of Nazareth». Such nouns are called distributive collectives or nouns with individual interpretation, i.e., the references are to the multiple objects.

D. Collective nouns designate the non-human have usually the singular agreement type.

\section{Agreement Patterns of the Collective Nouns}

As previously mentioned, Holes and Fischer et al. explain that the agreement in the singular is in accordance with the morphological form of the collective noun, while agreement in the plural indicates reference to the individuals. Furthermore, the statistical data indicate that the most common agreement type in Arabic newspapers is an agreement in the singular. Examples of this type of agreement are: din

(1) qāla l-ğgyšu n-nĭğìiyyu 'innahu qatala 150 mutamarri-

«The Nigerian army said that it had killed 150 rebels.» (alHayat $18^{\text {th }}$ September, 2013)

The collective nouns ğayš «army» is regarded as a singular noun, therefore agreement in the plural with this noun might be considered a mismatch between the morphological form of the noun and its agreement. The mismatch may make it difficult for the reader to understand the sentence. This claim draws support from an experiment conducted on the collective nouns in Dutch. One of the results was that collective nouns of low member level accessibility such as club, firma and organization, which are combined with a plural possessive pronoun, require more cognitive effort than sentences in which those collective nouns are combined with a singular pronoun. The

\footnotetext{
${ }^{39}$ BIBER AND LEECH, p. 61.
} 
resulting average reading times for plural agreement are slightly slower than for singular ones. ${ }^{40}$

Additional examples for agreement in the singular are:

(2) wa-'atbata ššsa 'bu l-kurdiyyu 'annahu ša 'bun yatațalla' 'ilā s-salāmi (aš-šarq al-'awsat $4^{\text {th }}$ October, 2013)

«The Kurdish people have proved that they long for peace.»

(3) fi mawsimi l-ḥağği mina l- 'àmi l-muqbili tah̆ruğu qāfilatun mina s-siniḡāli qāṣidatan l-'arāḍ̄ya l-ḥiğāziyyata lmuqaddasata li-tadhula l-qāhirata (al-'ahrām $5^{\text {th }}$ October, 2013)

«During the Hajj next year, a convoy from Senegal will leave facing the holy territory of Hijaz in order to enter Cairo.»

(4) wa-'a'rabati l-yūniskū 'an qalqihā mina istimrāri l-

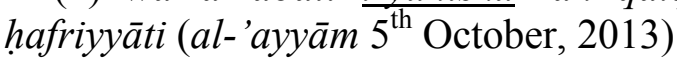

«UNESCO has expressed its concern over the continued excavations.»

(5) 'anhā ttihādu șinā'ati l-hăğari wa-r-ruhāmi 'amsi

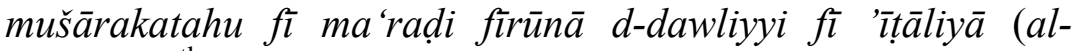
'ayyām $30^{\text {th }}$ September, 2013)

«The Association of Stone and Marble Industries completed its visit to the display in Verona in Italy.»

(6) 'afāda maṣdarun rasmiyyun 'anna mağlisa l-'amni $t$ tābi 'a li-l-'umami l-muttahidati șawwata 'amsi 'alā qarārin biša'ni tadmìri l-'aslihati l-kìmāwiyyati s-süriyyati (al-'ayyām $28^{\text {th }}$ September, 2013)

«An official source said that the Security Council which belongs to the United Nations voted last night to a decision regarding the destruction of chemical weapons in Syria.»

(7) 'adānat miṣru 'amsi l-hağamāti l-'irhābiyyata llatī šannathā ğamā'atu būku harām l-'irhābiyyatu (al-'ahrām $8^{\text {th }} \mathrm{Fe}$ bruary, 2015)

«Egypt condemned the terrorist attacks that were carried out by the terrorist organization Boko Haram.»

(8) haqqaqati l-firqatu l-mișriyyatu nağāhan kabīran ba'da 'an qaddamat 'urū dahā l-faniyyata l-muhtalifata (al-'ahrām $1^{\text {st }}$ September, 2014)

«The Egyptian band achieved a great success after appearing in various artistic performances.»

Thus, most of the collective nouns in journalistic Arabic are conceptualized as singular nouns, or as a single group. Yet we

\footnotetext{
${ }^{40}$ JOOSTEN ET AL., p. 108.
} 
cannot ignore the collective nouns which have both singular and plural agreements, and stand at the heart of our discussion in this section trying to refute the conventional argument presented in modern Arabic descriptions that agreement in the plural results only when the noun is conceptualized as more than one. It will be shown here that the distinction between a complex noun phrase and a non-complex noun phrase has a major effect on the agreement pattern, because complex collective nouns are more likely to attract plural agreement.

Collective nouns in any language are not always embedded by a local noun. Even when they are followed by an adjective (see Example 1), they still can be analyzed as singular nouns and not as complex noun phrases. However, there is a group of nouns that become complex noun phrases because it is necessary to add a completion in order to specify these nouns. Joosten et al. call such nouns highly relational because they are highly dependent on a contextual identification of the members. ${ }^{41} \mathrm{Col}-$ lective nouns such as group, herd, or swarm usually require more information about the identity of the members, and thus they are often followed by the of complement, as in: a group of boys, a herd of sheep, a swarm of wasps. Such nouns are to be found in Arabic, as for instance, in: mağmū'a «group», far $\bar{l} q$ «group», fi'a «group», «class» and tāaqim «team», «crew». If we look at a collective word huküma «government» it is obvious that it can refer only to the members of the government; however when a collective noun such as tâqim «crew» or «staff» is used the reference might be ambiguous. Even by adding a qualifier such as tạqim tibbiyyi «a medical staff», it still has no specification because it may refer to the doctors, or to the nurses, or to the paramedics, or even to all of them. But when an utterance such as tāqim mina l-'ațibb $\bar{a}$ ' $i$ «a team of doctors» is used, then the collective noun has a more specific application. What concerns us is the fact that the complexity of the noun is the main factor that causes the agreement to be in the plural and not in the singular due to the phenomenon called number attraction.

If we examine a sentence such as «Good grammar favored by listeners are often associated with people from an upper class.» The verb are exhibits a plural inflection because it agrees with the plural local noun listeners. ${ }^{42}$

Another example is "The key to the cabinets are on the table», where the verb are is affected by the number of the second noun in the noun phrase the key to the cabinets. This ef-

41 JOOSTEN ET AL., p. 89.

${ }^{42}$ K. Bock, K., K.M. Eberhard, L.C. Cutting, S.A. Meyer and H. SCHRIEFERS, «Some Attractions of Verb Agreement», Cognitive Psychology 43(2001), p. 85. 
fect of a second noun or, as it is called; a local noun is known as number attraction. This phenomenon is more common when the head noun is in the singular and the local noun is in the plural and not vice versa. ${ }^{43}$

The term, attraction is defined as follows:

«Normally, verbs in both Dutch and English agree in number with the head noun of the subject noun phrase, yielding sentences such as Membership in these unions was volunta$r y$. In attraction, the verb agrees instead with another noun in its vicinity, as in Membership in these unions were voluntary. We call the head of the subject noun phrase the agreement controller (e.g., membership), the number-carrying part of the verb the agreement target (e.g., the past tense of the copula $b e$ ), and the number-attracting noun phrase the local noun (e.g., unions) (...) Attraction is a kind of spurious resolution between conflicting number specifications (Corbett, 1983). Normally, the number of the agreement controller dominates this contest, but occasionally the number of a local noun takes over the control of verb agreement. ${ }^{44}$

Cases of collective head nouns followed by a local noun are very common in journalistic Arabic especially with a group of nouns mentioned in the following examples, while the potential attractor is a prepositional phrase structured from the preposition $\min +$ noun in the plural.

In Example 9, the head of the subject nouns phrase (controller) is $m a \breve{g} m \bar{u}$ ' $a$, which is grammatically singular feminine. It is followed by the partitive min, while l-ğunūd is the numberattracting noun (local noun) that causes all the syntactic elements following the noun phrase mağmī'a mina l-ğunūd to be in the plural rather than in the singular.

(9) fì waqtin bada'a l-ğayšu l-'isrā'îliyyu tanfìda hutțatin wāsi'atin li-ta'zīzi wa-našri quwwātihi (...) tamarradat măgmū'atun mina l-ğunūdi lladīna yahdumūna fì wahdati

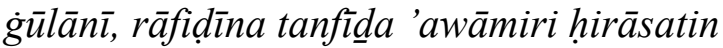

«At the time when the Israeli army began to carry out its broad plan to fortify

and scatter its forces (...), a group of solidiers serving in the Golani military unit rebelled, refusing to carry out guard duties.» (al-Hayat $16^{\text {th }}$ July, 2013)

(10) (...) 'ištakā mă̆mū'atun mina t-tuğğāari min 'anna $t$ taṣārịha llatī muniḥat li-l-muwātiniña (...) 'atarat bi-šaklin

43 A. STAUB, «On the Interpretation of the Number Attraction Effect: Response Time Evidence», Journal of Memory and Language 60(2009), p. 308-309.

${ }^{44}$ Bock ET AL., p. 85-86. 
kabìrin 'alā l-ḥarakati t-tiğāriyyati fì l-baladi, wa-țalabū bi'`̌̆gadi hallin li-hādihi l-muškilati

«A group of merchants complained that the licenses granted to residents adversely affected the trade in the town and demanded finding a solution to this problem.» (al-'ayyām, $9^{\text {th }}$ October, 2013)

Example 10 has the same structure as Example 2, i.e., a collective head noun is in the feminine singular, followed by the partitive min and local noun in the masculine plural. The agreement with the complex noun phrase is in the plural. As for the verb preceding the complex noun phrase, it is in the masculine singular and not the feminine because the verb refers to the

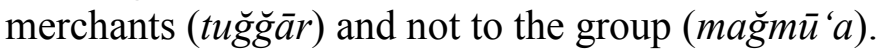

(11) yūğadu ḥāliyan fì süriyā farīqun min 20 habìran mina l'umami l-muttahidati wa-munazzamati hazri l-'aslihati lkìmyā'iyyati wașalu fi l-'awwali min tišrīn l-'awwali wabada' ù mihmatahum fi l-'išrāafi 'alā tafkīki t-tarsānati lkìmā'iyyati s-sūriyyati

«At present, there is in Syria a group of 20 experts from the UN and the organization for the prohibition of chemical weapons from the beginning of October and they have started their task of supervising the closure of the chemical weapon depots.» (al-'ayyām $9^{\text {th }}$ October, 2013)

In Example 11, the collective head noun fari $q$, is grammatically singular masculine, yet the local noun, 20 experts, takes over and thus the agreement is in the plural.

(12) wa-i 'tarafati ș-șahāfiyyatu Valiriya Māntū bi-'anna fi'atan min bā'ati suhufin rafaḍu bay'a nusahi l-mağallati bisababi muhtawāhā

«The journalist, Valeria Mantu, admitted that a group of newspaper vendors refused to sell copies of this journal because of its content.» (aš-šarq al-'awsat $21^{\text {st }}$ September, 2012)

Example 12 indicates again that the number of the local noun, ba' 'at șuhuf, is the element in the complex noun phrase that affects the agreement, which is in the plural.

In Example 13 the collective noun is found in an annexation structure that makes it a complex noun phrase. The agreement in the plural of the verb and the suffixed pronoun is affected by the number of the nomen regens which is in the plural.

(13) wa-'atnā tāaimu l-mufattišina 'alā mustawā l-'amali $l$ mumtāzi fi l-madrasati (...) wa-'abdawu sti'dādahum lita 'âwunin ma'a l-madrasati (Panet $4{ }^{\text {th }}$ February, 2015)

«The team of inspectors praised the level of the excellent work in the school and expressed their willingness to cooperate with the school.» 
(14) kayfa tuțālibu l-ḥukūmatu ma šra t-tuğğgarri bi-tahfị̂di 'as 'āri mabī'ätihim wa-hiya tarfa' $u$ 'as 'àra kulli mā tatahakkamu fì 'intāğihi wa-bay 'ihi li-n-nāsi (al-'ahrām $7^{\text {th }}$ February, 2014)

«How can the government require all merchants to lower prices when it controls the production and sale of merchandise/groceries to the people?»

When the collective nouns mağmū ' $a$, fi' $a$, firqa and țāqim have no complements, they tend to attract the singular agreement as the following examples indicate:

(15) dakkat țâ'irātu l-'abātši mağmū'atan musallahatan ğanūba rafah kānat taqūmu bi-'amaliyyati 'akminati li-lmuwātiniña (al-'ahrām 14 ${ }^{\text {th }}$ February, 2015)

«South of Rafah, Apache helicopters pounded an armed group that had set ambushes for the citizens (of the area).»

(16) 'inna hunāka fi'atan ('aṣbahat kabìratan) lā tă̆idu fi kulli tilka l-'anwā'i htiyāğahā l-munāsiba mina s-sakani (al'ahrām 22 ${ }^{\text {nd }}$ December, 2013)

«There is a group (that has become big) and cannot find in all these types (of solutions) a suitable solution for housing.»»

(17) at-țāqimu t-țibbiyyu fì n-nuqtati t-tābi 'ati li-wikālati l'ūnrū 'àlăga'adadan mina l-marḍā (aš-šarq al-'awṣat 11 $1^{\text {th }}$ March, 2015)

«A medical staff that works at the care station, and belongs to UNRWA, treated several patients.»

(18) qāla 'arsīn finğir mudarribu nādā 'arsināl 'inna farīqahu qtaraba mina t-ta 'āqudi ma'a l-faransiyyi tīyari hinrī (al-'ahrām $1^{\text {st }}$ September, 2014)

«Arsène Wenger, the coach of the Arsenal Football Club, said that his team was close to signing a contract with the French football player, Thierry Henry.»

Examples 9-14 indicate that the local nouns that are grammatically plural cause plural agreement. It is important to note that, in this case, the agreement in the plural has nothing to do with notional agreement, i.e., the reference to the group or to the individuals has no significant effect on the number of the verbs, adjectives and pronouns. ${ }^{45}$ Examination of the corpus shows that when the collective nouns, mağmī' $a$, farì $q$, fi' $a$, $m a \check{s} a r$ and $t \bar{a} q i m$, are so-called complex noun phrases there is a preference for agreement in the plural; however it does not necessarily mean that agreement in the singular cannot be found with these nouns. In Example 19 there is an annexation structure, while the adjective $d$-dawliyyina is in the plural and

\footnotetext{
${ }^{45}$ BOCK ET AL., p. 108.
} 
refers to the nomen regens l-hubara '. As for the agreement, all pronouns referring to the complex noun are in the singular.

(19) waṣala farīqu l-hubarā'i d-dawliyyīna llad̄̄ yar'asuhu $\bar{A} k \bar{\imath}$ Sìlsitrūm (...) 'ilā maqari 'iqāmatihi fì funduqi four seasons

«A group of international experts which $\bar{A} k \overline{1}$ Sīlsitrūm heads found its accommodation at the Four Seasons hotel.» (al'ayyām $26^{\text {th }}$ September, 2013)

There are several explanations for the agreement type in Example 19. First, with regard to the number represented in the speaker's messages, ${ }^{46}$ it might be argued that the reporter who wrote this article sees the group in his mind and not the individuals. It should be mentioned that the sentence could also paraphrased as follows: wa-wașala farīqu l- hubarā' d-dawliyyina llad̄ī yar'asuhum Ākī Sīlsitrūm (...) 'ilā maqar 'iqämatihim «A group of international experts led by $\bar{A} k \overline{1}$ Sinlsitrūm came to their accommodation.»In other words, the pronouns referring to the subject noun phrase have a distributive value and can refer to the individuals composing the group.

The agreement in the singular could be also explained by the structure of the noun phrase. Unlike Examples 9-13, in which the complex noun is composed of the collective head noun in the singular + partitive min + noun in the plural, the noun phrase in Example 19 is in the construct state. However, Example 20 eliminates this possibility by showing that a noun phrase constructed by the partitive $\min$ can have an agreement in the singular.

(20) 'inna hādihi l-fi'ata mina l-muhāğirīna 'aṣbahat tă̆idu l-yawma 'amalan fíl-magribi

«Indeed this group of immigrants finds work today in Morocco.» (aš-šarq al-'awsat $28^{\text {th }}$ October, 2010)

The following examples however, might strengthen the argument that the complexity of the noun phrase affects the agreement. Thus, in Examples 21 and 22, the collective noun $\breve{g u m h} \bar{u} r$, like most collective nouns in Arabic, is not complex and attracts agreement in the singular.

(21) wa-yantazimu hādihi l-'ayyāma (...) ğumhūrun 'arīdun li-mušāhadati l-'urūại s-sīnamā' 'iyyati 'alā šāšatin mutağawwilatin

«A general public is, at the moment, organizing films on a screen which will move from place to place.» (ăs-šarq al'awsat $27^{\text {th }}$ June, 2013)

(22) fa-l-ğumhūru yurìdu 'an yahruğa mina l-fìlmi sa 'ìdan

${ }^{46}$ IBID., p. 86. 
«And the public wants to leave the movie when it is happy.» (aš-šarq al-'awsat $26^{\text {th }}$ December, 2012)

In Example 23, however, the local noun l-mutaqqafina was added to the collective head noun, ğumhür. In this instance, the agreement in the plural was caused by the attraction, i.e., the syntactic elements agree with the number of the local noun and not with the (grammatical) number of the collective head noun.

(23) (...) l-wazìru Ȟüğa hatafa fi ğumhūri l-mutaqqafina lladīna ltaqāhum masā'a 'awwalin min 'amsi fì qāa'ati lmuḥậ̣arāti (...) țāliban minhum 'an yatawăğgahū bi-n-naqdi 'ilā wizāratihi

«The minister, Hü $\breve{g} a$, told the educated public that he had met them in the evening of the day before yesterday in the lecture hall $(\ldots)$ while asking them to refer their criticism to his office.» (aš-šarq al-'awsat 12 $2^{\text {th }}$ March, 2010)

An additional factor that affects the agreement pattern is the usage of a vocative structure which is usually found in op-eds, i.e., articles in which the writer expresses his opinion. In the following examples, the vocative particle $y \bar{a}$ ' $\mathrm{O}$ ' is involved. The direct address to a certain group in this case is in the plural. Thus, in Example 24, the verb precedes the collective noun in the plural. In Example 25, the verb in the imperative is in the plural, and likewise in Example 26, all pronouns referring to the collective noun are in the plural.

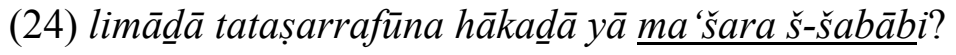

«Why do you behave like this, O young people (the sector of young people?).» (Panet $30^{\text {th }}$ April, 2008)

(25) yā 'ahla t-țībati ḥdarū s-sirqata

«O people of those who have a good nature beware of stealing.» (Panet $4^{\text {th }}$ October, 2013)

(26) garībun 'amrukum yā ma 'šara l-bašari, yā man 'antum baqāyā dikri wa-șafhatin țwiyat min kitābi n-nisyāni

«It is strange - your issue, $\mathrm{O}$ people (mankind) $\mathrm{O}$ whoever you are, the relics of a memory and a page which was forgotten (to be mentioned) in the book of forgetfulness.» (Panet $2^{\text {nd }}$ October, 2007)

A personal address has more impact on the group, because any command, demand, request or desire presented by the addresser is directed to each member of the group, so each one feels responsible to fulfill the addresser's wish.

In this category, another case of direct speech should be mentioned. Occasionally the spokesman of a certain group is being interviewed. The examined texts show that $\mathrm{s} / \mathrm{he}$ answers using the first person plural. For example, in a report on the Sudanese revolution front (al-ğabha t-tawriyya s-sūdāniyya), 
when the spokesman was asked about their latest activity in Sudan, he replied:

(27) nahdaru hukūmata (hizb) l-mu'tamari l-wațaniyyi fì stiḩdāmi l-'unfi l-mufrați ḍidda l-mutazāhiriña l-muslimina

«We warn the government (party) of the national congress/convention against using excessive violence against the Muslim protesters.» (aš-šarq al-'awsat $29^{\text {th }}$ September, 2013)

In his answers, the spokesman could use the collective noun

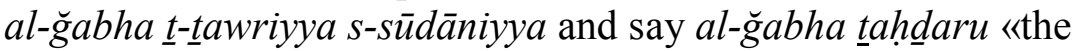
front warns» as he represents this organization. Instead he uses a verb in the first person plural as if he were presenting the approach of the members and not of the group.

Finally, we refer to a small group of collective nouns that appears only with agreement in the plural, as is shown in the following examples:

(28) wa-kāna šššl'atu llad̄ina yušakkilūna 16 fi l-mi'ati mina n-nāhibina 'abraza l-hāsirīna 'id nhafada 'adaduhum min 17 nā'iban 'ilā 8 nuwwābin

«The Shiah, which constitutes 16 percent of the voters, were the prominent losers since their number decreased from 17 representatives to 8 representatives.» (al-Hayat $28^{\text {th }}$ July, 2013)

(29) aššš́atu murtabațūna bi-n-nizāmi s-sūriyyi wa-ssunnatu bi-l-mu'āraḍati

«The $\check{S}_{\bar{l}}$ ' $a$ are linked to the Syrian regime and the Sunna are linked to the opposition.» (aš-šarq al-'awsat $23^{\text {rd }}$ November, 2013)

(30) nahaḍtu min makān̄̄ (...) wa-wağadtu l-qawma muhtalifìna, fa-farīqun minhum yawaddu l-ğulüsa wa-la 'ba l-balūti

«I got up from my place and I found the people disagreeing (...) and a group of them (of the people) wants to sit and play Baloot (a card game).» (aš-šarq al-'awsat $23^{\text {rd }}$ June, 2008)

(31) naḥnu 'alā tiqatin bi-'anna 'ahla n-nāṣirati lā yurìdūna husșümātin lafạiyyatan tāfihatan (Panet $28^{\text {th }}$ September, 2013)

«We are sure that the residents of Nazareth do not want to seek verbal and trivial fights.»

Unlike most of the collective nouns that are considered as singular nouns, the two nouns, $\breve{s} \bar{l}^{\prime} a$ and qawm, are conceptualized as more than one, i.e., the reference is always to the individual member and not to the group. The agreement type in these cases has nothing to do with the fact that the agreeing elements are distributive or less distributive. It seems, for example, that the nominal predicate murtabatūna in Example 29 should have been in the singular rather than the plural because it is more reasonable to say that the $s^{\prime} \bar{l}^{\prime} a$ as a group (the 
second largest denomination of Islam) is attached to the regime. Although the nominal predicate is less distributive and it is most likely that it applies to the collection level, it is in the plural.

As for the collective noun, qawm, one cannot ignore the fact that the agreement with this noun in the Qur'ān is always in the plural. No agreement in the singular was found, except for the verb preceding these nouns that are always in the masculine singular.

As there are collective nouns that always attract agreement in the singular, regardless of the type of the agreeing elements, there are several collective nouns with agreement in the plural. Thus, in the case of $s \bar{l}^{\prime} a$, the reference in the newspapers is to the adherents while in the noun, qawm, the reference is to the people.

Finally, an additional aspect must be considered in the discussion about agreement types. One cannot ignore the fact that the personal dialect of the journalists and their language level might also affect the agreement pattern of collective nouns. However, since the identity of the writer is not always known it would be hard to prove such effect on the writing style. Yet the agreement types presented above are common to Egyptian, Syrian and Israeli newspapers, and this might indicate that these are not the personal dialect or writing styles that affect the agreement type, but rather there are conventional agreement types with collective nouns in modern journalistic Arabic.

\section{Conclusions}

Collective nouns are defined as nouns that are morphologically singular with multiple references, singular or plural. As for the collective nouns used in Arabic-language newspapers, there are modern words that have been introduced into Arabic as a result of the influence of Western languages, particularly English. Examples of such words are küngris «congress« and barlamān «parliament». Along with these nouns, there are also collective nouns that can be found in classical sources such as the Qur'ān, e.g., qawm «tribe» or «people», nafar «group of people» and lu'lu' "pearls». As for the classical noun, faw $\breve{g}$, which means «a group of people» in the Qur'ān, it received the modern meaning «graduates». Examination of the collective nouns collected in this paper has raised the need to re-examine the principles presented by grammarians for the classification of collective nouns. In other words, it is impossible to classify the collective nouns used in Arabic journalism according to the distinction between human and non-human nouns with or without nomen unitatis. A correct classification should be based on the agreement pattern of the collective nouns. Thus, we might distinguish between three groups of collective nouns: those that have agreement in the singular; those that have 
agreement in the plural; and those that have agreements both in the singular and in the plural.

Based on the statistical data presented in this paper, it might be well argued that the prominent agreement pattern is in the singular. Of 50 collective nouns designating the human, 42 have one agreement type in the singular. These data indicate that collective nouns in Arabic journalism are regarded as wholistic collectives rather than distributive collectives, i.e., these nouns have a sense of a single group or they are conceptualized as one group without any reference to the objects.

As for the agreement type in the plural, it has been shown that this pattern is limited to three cases. First, agreement in the plural with collective nouns can be found together with the following nouns: mağmū' $a$, farīq, fi'a, ma ‘̌sar and tāqqim. These collective nouns are expanded through the local noun in the plural and hence the collective noun becomes more specified. It is the number of the local noun that causes the agreement to be in the plural.

Second, when direct speech or, more precisely, a vocative structure appears in the article, then the agreement would be in the plural. Third, the collective nouns qawm, šs ' $a$ and 'ahl, (followed by a name of a city) are always with an agreement in the plural. 


\section{Bibliography}

B. AREMo, «On Some Uses of Singular Collective Nouns», English Today 1(2005), p. 52-55.

D. Biber, S. Conrad And G. Leech G., Longman Student Grammar of Spoken and Written English, Harlow, Essex, 2002.

R. BlachÈRe, Elements de l'Arabe Classique, Paris, 1958.

K. Bock And K.M. Eberhard, «Meaning, Sound and Syntax in English Number Agreement» Language and Cognitive Processes 8.1(1993), p. 57-99.

K. Bock, K.M. Eberhard, L.C. CutTing, S.A., Meyer AND H. SCHRIEFERS, «Some Attractions of Verb Agreement», Cognitive Psychology 43(2001), p. 83-128.

C. Brockelmann, Arabische Grammatik, Leipzig, 1965.

R. Charles And P. Many, «How Language Collectives Comprise Journalistic Accuracy», ETC: A Review of General Semantics 51.1(1994), p. 88-94.

G. Corbett, «Resolution Rules: Agreement in Person, Number, and Gender», in G. GAZDAR - E. KLEIN - G. PULluM (eds), Order, Concord, and Constituency, Dordrecht, 1983, p. 175-206.

D.A. CRUSE, «Number and Number System», in R.E. ASHER - J.M.Y. SIMPSON (eds), The Encyclopedia of Language and Linguistics, vol. 5, Oxford, 1994, p. 2857-2861.

I. DePrAetere, «On Verbal Concord with Collective Nouns in British English», English Language and Linguistics 7.1(2003), p. 85-127.

A. FISCHER, «Die Terminologie der arabischen Kollektivnomina», Zeitschrift der Deutschen Morgenländischen Gesellschaft 26(1940), p. 12-24.

W. Fischer, H. El-Ayoubi AND M. LANGER, Syntax der arabischen Schriftsprache der Gegenwart, Wiesbaden, 2001.

W. FISCHER, Grammatik des klassischen Arabisch, Wiesbaden, 2002.

H. FleISCH, Traité de Philologie Arabe, Beirut, 1961.

H.L. FLEISCHER, Kleinere Schriften,C. Osnabrück, 1968.

C. Holes, Modern Arabic: Structures, Functions, and Varieties. London, 1995. 
K.R. Humphreys AND K. BocK, «Notional Number Agreement in English», Psychonomic Bulletin \& Review 12.4(2005), p. 689-695.

F. Joosten, «De Boorbaarheid van Nederlandse Collectiva», Over Taal 40(2001), p. 77-79.

F. Joosten, G. De Sutter, D. Drieghe, S. Grondelaers, R.J. HARTSUIKER AND D. SPEELMAN, «Dutch Collective Nouns and Conceptual Profiling», Linguistics 45.1(2007), p. 85-132.

M. LEVIN, «Concord with Collective Nouns Revisited», ICAME Journal, 23(1999), p. 21-33.

M. LEVIN, «Collective Nouns and Language Change. English Language and Linguistics», 10.2(2006), p. 321-343.

J. LyOns, Semantics, Cambridge, 1987.

AL-MuBARRAD, Abū al-'Abbās Muhammad Ibn Yazīd, alMuqtadab. Beirut, 1994.

R. Quirk, S. Greenbaum, G. Leech And J. Svartvik, $A$ Comprehensive Grammar of the English Language, London and New York, 1986.

A. Rozumko, «Countable, Uncountable and Collective Nouns in Early Eighteenth Century English. Studia Anglica Posnaniensia 32(2002), p. 131-159.

I. Sparkes, A Dictionary of Collective Nouns and Group Terms, Detroit, 1975.

A. Staub, «On the Interpretation of the Number Attraction Effect: Response Time Evidence», Journal of Memory and Language 60 (2009), p. 308-327.

SīBAWAYHI, Abū Bišr ‘Amr, al-Kitāb, Beirut, 1999.

K. Versteegh, The Arabic Language, Oxford 2001.

W. Wright, A Grammar of the Arabic Language, Cambridge, 1971.

IBN YA'Īš MuWAFFAQ AL-DĪn, Šarh al-mufașșal, Beirut, 1994. 


\section{Abstract}

The category of collective nouns in classical Arabic has been discussed by traditional grammarians of the Arabic language. They provide a clear definition of the notion of collective nouns and also present lists of such nouns. As for modern written Arabic, it might well be argued that the category of the collective noun has not received sufficient attention in grammatical descriptions of modern written Arabic. Western grammarians usually address this category when they discuss the topic of the plural in Arabic; however, they provide a laconic explanation which mainly revolves around the morphological aspect, especially the distinction made between collective nouns which have nomen unitatis and collective nouns which do not have nomen unitatis. They also mention some examples taken from traditional descriptions such as qawm «people» or nahl «palmtrees». When reading Arabic-language newspapers, one may notice the use of multiple and diverse collective nouns. The number of collective nouns in journalistic Arabic language has grown, especially due to the interaction of Arabic with other languages such as English, and therefore lists of collective nouns should be updated. Furthermore, examination of collective nouns in journalistic Arabic shows that the traditional classification of collective nouns which is adopted from classical Arabic and based on the dichotomy between human and nonhuman nouns, and nouns with or without nomen unitatis should be re-examined. Thus, in this paper a different classification based on the idea of the level of member interpretation is proposed. It means that some collective nouns, especially those that indicate bodies that were elected or selected, as for example huküma «government» are considered in Arabic as a collection of things taken as a whole. With these nouns, which are grammatically and conceptually singular and called wholistic collectives, a reference to the members of this collection has not even been considered. On the other hand, a reference to the individuals can be made by using collective nouns such as mă̆mü'a «group» which are called distributive collectives. However, the reference to the individuals is usually made when a subsequent noun or, as it is called, a local noun is added to the collective head noun, as for example mağmū'atun mina $t$ tulläbi «a group of students». This classification of collective nouns into two primary groups also affects the agreement with the collective nouns. The data presented in this paper, based on a corpus consisting of 3,324 instances of collective nouns taken from various Arabic newspapers, show a preference of agreement in singular. Agreement in the plural is registered in three cases: when the collective noun is a complex noun phrase as, for example, mağmū 'a min t-țullābi; when the collective noun

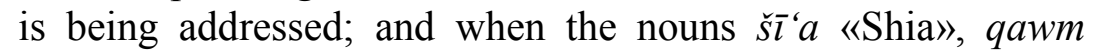
«people» and 'ahl «people»/«citizens» (followed by a name of a city) appear in the sentence. 
